\title{
Microsatellite DNA analysis does not distinguish malignant from benign pleural effusions
}

\author{
F. ECONOMIDOU ${ }^{1}$, E.G. TZORTZAKI ${ }^{1,2}$, S. SCHIZA ${ }^{1}$, K.M. ANTONIOU ${ }^{1}$, \\ E. NEOFYTOU ${ }^{2}$, M. ZERVOU $^{2}$, I. LAMBIRI ${ }^{1}$ and N.M. SIAFAKAS ${ }^{1,2}$ \\ ${ }^{1}$ Department of Thoracic Medicine, University Hospital and ${ }^{2}$ Molecular Pulmonology \\ Research Laboratory, Medical School, University of Crete, Heraklion 71110, Greece
}

Received September 5, 2007; Accepted October 8, 2007

\begin{abstract}
Distinguishing malignant from benign pleural effusions using routine cytology is a common diagnostic problem. Recently, genetic alterations, including microsatellite instability (MSI) and loss of heterozygosity (LOH), have been described in malignant pleural effusions and proposed as methods improving diagnostics. The purpose of this study was to evaluate a panel of molecular markers for the detection of genetic alterations of cells in pleural effusions and to determine their diagnostic value as an additional test to cytologic examination. Pleural fluid and peripheral blood from 48 patients (36 male and 12 female, median age 71 years) were analyzed. Twenty-six patients had malignant pleural effusion, including 23 lung cancer and three metastatic non-pulmonary carcinoma. The control group consisted of 22 patients with benign pleural effusions. Only 14 malignancy-associated pleural effusions were cytology-positive for malignant cells (54\%), whereas all benign pleural effusions were negative. DNA was extracted from all the samples and analysed for MSI and/or LOH using the following microsatellite markers: D3S1234, D9S171, D12S363, D17S250, D5S346 and TP53Alu, located at five chromosomal regions: 3p, 9p, 12q, 17q, 5q. Microsatellite analysis of the pleural fluid pellet exhibited genetic alterations in two neoplastic pleural fluid cases and in one inflammatory case. Two out of $26(7.6 \%)$ patients with malignant pleural effusion showed genetic alterations. One exhibited MSI in three different micro-satellite markers (D17S250, D9S171, D3S134) and the other showed LOH in marker D3S134. One out of $22(4.5 \%)$ patients with benign pleural effusion showed LOH in marker D3S134. In conclusion, genetic alterations at the level of microsatellite DNA, were detected only in very few cases of malignant
\end{abstract}

Correspondence to: Dr Eleni G. Tzortzaki, Department of Thoracic Medicine, University Hospital, Medical School, University of Crete, Heraklion 71110, Crete, Greece

E-mail: tzortzaki@med.uoc.gr

Key words: microsatellite instability, loss of heterozygosity, neoplastic, pleural fluid, lung cancer pleural effusions, and in one case of benign pleural effusion. Thus, our data suggest that microsatellite DNA analysis does not facilitate the diagnosis of malignant pleural effusion.

\section{Introduction}

Pleural effusions are commonly found in patients with cancer, whereas $20 \%$ are due to malignancy and $50 \%$ are due to lung cancer $(1,2)$. A malignant pleural effusion may be the initial presentation of cancer in $10-50 \%$ of patients (3). Current laboratory techniques are not capable, in the majority of lung cancer cases, to detect tumors before they have already progressed beyond effective treatment. Consequently, there is a high mortality rate with a five-year overall survival rate of 5\% (4). The presence of an effusion affects the prognosis and the treatment of the disease. Thus, it is of paramount importance to detect cancer cells in the fluid with the greatest specificity and sensitivity. Cytology is the standard method used for the diagnosis of malignant effusion. However, the cytological interpretation of pleural fluids can be challenging, and its diagnostic accuracy is limited $(5,6)$. The sensitivity of conventional cytology ranges from 43 to $71 \%$ with an average of 58\% (7-9). A generally accepted view is that despite $40 \%$ of malignant effusions has negative cytology; there are cancer cells that escape light microscopy detection (3). Thus, many additional methods have been evaluated to improve the diagnostic accuracy of cytology and to avoid further invasive diagnostic techniques.

Lung cancer is characterized by the accumulation of multiple genetic and/or epigenetic alterations, including those that result in the activation of oncogenes and the inactivation of tumor suppressor genes $(10,11)$. Genetic damage has been identified at multiple chromosomal sites (i.e., loci) in lung cancer cells. Deoxyribonucleic acid (DNA) microsatellites (MSI) are highly polymorphic markers used for genome mapping in many organisms, including humans (12). Microsatellite DNA instability (MSI) has been investigated in a wide range of benign and neoplastic disorders (13-21). However, there are only few reports evaluating the role of genetic markers as a tool to improve the diagnostic yield of patients who present with a de novo pleural effusion $(22,23)$. Lee et al (22), investigated microsatellite alterations in 40 patients with malignant pleural effusion (ME) and 17 patients 
with tuberculous pleurisy (TB), in four microsatellite markers. Twenty-five ME cases (63\%) exhibited microsatellite alterations in at least one marker, while TB patients exhibited a $35 \%$ positive rate. In another study, Woenckhaus et al (23) investigated genetic alterations in pleural fluid (supernatants and cellular sediments) from 14 patients with malignancy and 6 with benign pleural effusions using 12 microsatellite markers and detected molecular alterations in $91.6 \%$ of the matched tumor tissue samples and in $71 \%$ of the malignant pleural supernatants (23). However, the molecular analysis of the pleural cellular sediment revealed a positivity of only $7 \%$ (23), which is conflicting with the results by Lee et al (22). Woenckhaus et al (23) also reported that tumor DNA is also detectable in cell-free body fluid, as the supernatant.

In order to determine if the molecular analysis of pleural fluid pellet could improve diagnostic utility, we investigated MSI and/or LOH in six microsatellite markers in pleural fluid and peripheral blood from 48 patients (26 with malignant and 22 with benign pleural effusion). The results of this study showed that MSI and LOH are rare findings in malignant pleural effusions and thus could not distinguish malignant from benign disease.

\section{Materials and methods}

The study was approved by the Ethics Committee of our hospital, and before the thoracentesis all patients signed an informed consent. Forty-eight patients (12 female and 36 male) who treated for pleural effusion from 2005 to 2006 at the Department of Thoracic Medicine of the University Hospital of Crete were included. The median age was 71 years (38-97 years). Twenty six patients were diagnosed to suffer from malignant pleural effusion median age 72.5 years, (48-88 years), including 23 with lung cancer and three with metastatic non-pulmonary carcinoma. Those patients had a histologically confirmed pulmonary malignancy, including non-small cell lung cancer $n=16$, small-cell lung cancer $n=6$, mesothelioma $n=1$ and metastatic non-pulmonary carcinoma n=3 (two breast cancers and one cancer of endometrium). Nineteen patients had a long-term smoking history (median pack years 60) and seven were non-smokers. The control group with benign pleural effusions (undiagnosed exudates $\mathrm{n}=7$, congestive heart failure $\mathrm{n}=3$, parapneumonic effusions $\mathrm{n}=11, \mathrm{TBC} \mathrm{n}=1$ ), included patients with a median age of 66.5 years (38-97 years). Seventeen patients had a long-term smoking history (median pack years 30 ) and 5 patients were non-smokers. Cytology of the pleural fluid was performed following routine technique and the results were evaluated by two independent experienced cytologists. Both were unaware of the clinical data of the patients. Only 14 malignancyassociated pleural effusions were cytology-positive for tumor cells, whereas all 22 patients with benign pleural effusions were diagnosed as negative for malignant cells.

Cytological samples and DNA isolation. Pleural fluid and peripheral blood were obtained from all patients. All samples were stored at $-80^{\circ} \mathrm{C}$ for DNA extraction. To obtain maximum recovery of pleural fluid cells, specific centrifugal filter devices (Centricon Plus-20, Millipore Life Science, USA)
Table I. The microsatellite DNA markers analysed in the study, the corresponding chromosomal region and the candidate gene(s).

\begin{tabular}{lll}
$\begin{array}{l}\text { Microsatellite } \\
\text { marker }\end{array}$ & $\begin{array}{c}\text { Chromosomal } \\
\text { location }\end{array}$ & \multicolumn{1}{c}{$\begin{array}{c}\text { Candidate } \\
\text { gene }\end{array}$} \\
\hline D17S250 & 17q11.2-q12 & $\begin{array}{l}\text { Apoptosis-antagonizing } \\
\text { transcription factor } \\
\text { Colony-stimulating } \\
\text { factor-3 (granulocyte) }\end{array}$ \\
D9S171 & $9 \mathrm{p} 22-\mathrm{p} 21$ & $\begin{array}{l}\text { Tumor suppressor } \\
\text { candidate 1, (TUSC1) } \\
\text { Interferon, ß-1, fibroblast } \\
\text { (IFNB1) }\end{array}$ \\
& & $\begin{array}{l}\text { Interferon, } \omega \text {-1 (IFNW1) } \\
\text { Fragile histidine triad } \\
\text { gene (FHIT) }\end{array}$ \\
D3S1234 & $3 \mathrm{p} 14.2$ & KRAS2 oncogene \\
D12S363 & $12 \mathrm{p} 12.3$ & $\begin{array}{l}\text { Adenomatous polyposis } \\
\text { coli (APC) }\end{array}$ \\
D5S346 & $5 \mathrm{q} 21-\mathrm{q} 22$ & Tumor protein p53 (TP53) \\
& $17 \mathrm{p} 13.1$ &
\end{tabular}

were used. The device can concentrate up to $20 \mathrm{ml}$ aqueous biological solutions, as pleural fluid, down to $150 \mu$ l. Pleural fluid was centrifuged $(1200 \times \mathrm{g}$ for $30 \mathrm{~min})$ at $4^{\circ} \mathrm{C}$. Cellular pellet was used for DNA extraction. DNA was extracted with the QIAamp (Qiagen extraction kits, QIAamp DNA blood maxi mini kits, Qiagen Inc.). DNA samples were stored at $4^{\circ} \mathrm{C}$.

Six polymorphic microsatellite markers were used to assess LOH and MSI (D17S250, D9S171, D3S1234, D12S363, D5S346, TP53Alu), and are described in detail in Table I. All markers have been shown to be located closely to candidate genes involved in cancer pathogenesis (24-28). The sequences of the microsatellite markers used were provided through the NCBI database (www.ncbi.nlm.nih.gov).

The polymerase chain reaction (PCR) technique was used to amplify DNA sequences. PCRs were performed in $50 \mu 1$ final volume reaction mixtures in a PTC-100 thermal cycler (M.J. Research Inc., Watertown. MA, USA), using the Qiagen Taq PCR core kit (Qiagen Inc.). Forward primers were labeled with the Licor IR800 fluorochrome. Reactions were denatured for $5 \mathrm{~min}$ at $95^{\circ} \mathrm{C}$ and the DNA was subsequently amplified for 30 cycles at 95,55 and $72^{\circ} \mathrm{C}$ during each step. The PCR products were analyzed and visualized by electrophoresis in $8 \%$ Long Ranger polyacrylamide (BMA, Rockland, ME, USA)/7 M urea sequencing gels in a Licor 4200 DNA sequencer (Lincoln, NE, USA). Alleles were sized with GeneProfiler v3.54 software (Scanalytics, USA). LOH and MSI were identified by comparing electropheretic patterns of the microsatellite markers of DNA of pleural samples versus peripheral blood demonstrating a shift of one or both of the 
Table II. Anthropometrical and clinical characteristics of patients with malignant and benign pleural effusion.

\begin{tabular}{|c|c|c|c|c|c|c|}
\hline Patient data & \multicolumn{3}{|c|}{ Malignant group } & \multicolumn{3}{|c|}{ Benign group } \\
\hline No. of patients & \multicolumn{3}{|c|}{26} & \multicolumn{3}{|c|}{22} \\
\hline Male/Female & \multicolumn{3}{|c|}{$21 / 5$} & \multicolumn{3}{|c|}{$15 / 7$} \\
\hline $\begin{array}{l}\text { Median age } \\
\text { (years), range }\end{array}$ & \multicolumn{3}{|c|}{$72.5(48-88)$} & \multicolumn{3}{|c|}{$66.5(38-97)$} \\
\hline Smokers (\%) & 19 & (73) & & 17 & (77) & \\
\hline Non-smokers (\%) & 7 & $(27)$ & & 5 & (23) & \\
\hline $\begin{array}{l}\text { Median pack } \\
\text { years (py), range }\end{array}$ & 60 & $(0-100)$ & & 30 & $(0-65)$ & \\
\hline \multicolumn{7}{|l|}{ Diagnosis } \\
\hline & \multirow{2}{*}{\multicolumn{3}{|c|}{$\begin{array}{l}\text { Lung cancer } \\
\text { effusions } \\
\text { Metastatic } \\
\text { carcinoma } \\
(2 \text { breast } \mathrm{Ca}, 1 \\
\text { endometrium } \mathrm{Ca})\end{array}$}} & \multicolumn{3}{|c|}{ Parapneumonic 1} \\
\hline & & & & \multicolumn{2}{|c|}{$\begin{array}{l}\text { Undiagnosed } \\
\text { exudates } \\
\text { Congective } \\
\text { heart failure } \\
\text { TBC }\end{array}$} & 3 \\
\hline
\end{tabular}

alleles, thus, generating novel alleles as indicated by an addition or deletion of one or more repeats units. Two scientists who were not aware of the clinical characteristics of the subjects performed independent readings.

Statistical analysis. Statistical analyses were performed using the SPSS version 10.0 (SPSS Inc., Chicago IL, USA). Comparisons between groups were made using unpaired t-test, paired t-test or Mann-Whitney $U$ tests as appropriate. A $\mathrm{p} \leq 0.05$ was considered statistical significant.

\section{Results}

The demographic parameters, smoking history and the final diagnosis of the two studied groups are presented in Table II. The mean values of total protein levels, lactate dehydrogenase (LDH) concentration (upper limit for serum LDH, $480 \mathrm{IU} / \mathrm{l}$ ), glucose levels, $\mathrm{pH}$ and cell count type in pleural fluids of both groups are shown on Table III. DNA was successfully extracted in satisfactory quantities from all cytological samples. Fig. 1 shows representative electrophoretic patterns of microsatellite instability (MSI) and stability (MSS), in two different microsatellite markers (D17S250, D9S171). Two out of 26 (7.6\%) patients with malignant pleural effusion showed genetic alterations. One patient with non-small cell lung cancer exhibited MSI in three different microsatellite markers (D17S250, D9S171, D3S134) and 1 patient with non-small lung cancer exhibited LOH in marker D3S134. One out of $22(4.5 \%)$ patients with benign pleural effusion (parapneumonic) showed LOH in marker D3S134. All the other samples from both groups showed microsatellite stability in the markers tested.

\section{Discussion}

Genetic damage has been identified at multiple chromosomal sites (i.e., loci) in lung cancer cells. The possibility of detecting early genetic alterations (microsatellite instability and loss of heterozygosity) in DNA of pleural fluid has been poorly explored in the literature $(22,23)$. We questioned whether this damage could be detected in the pleural fluid pellet cells of malignant exudations. Therefore, six microsatellite markers at five different chromosomal loci were chosen, as they have been associated with genes involved to the patho-genetic cascade of lung cancer.

To the best of our knowledge, only two previous studies $(22,23)$ have investigated MSI or/and LOH in neoplastic pleural effusions. Lee et al (22), investigated microsatellite alterations using extensive cell segregation in the pleural fluid of 40 patients with pleural effusion associated with

Table III. Laboratory findings of malignant and benign pleural effusions.

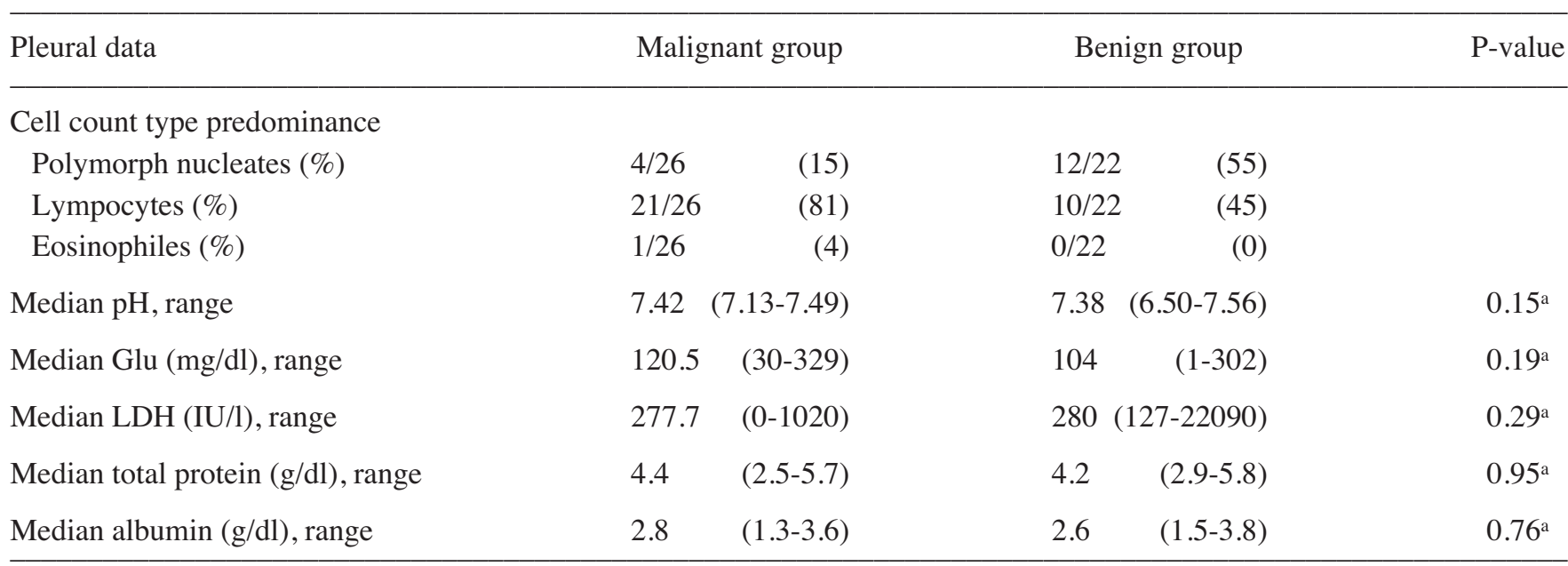

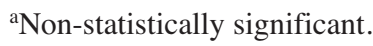




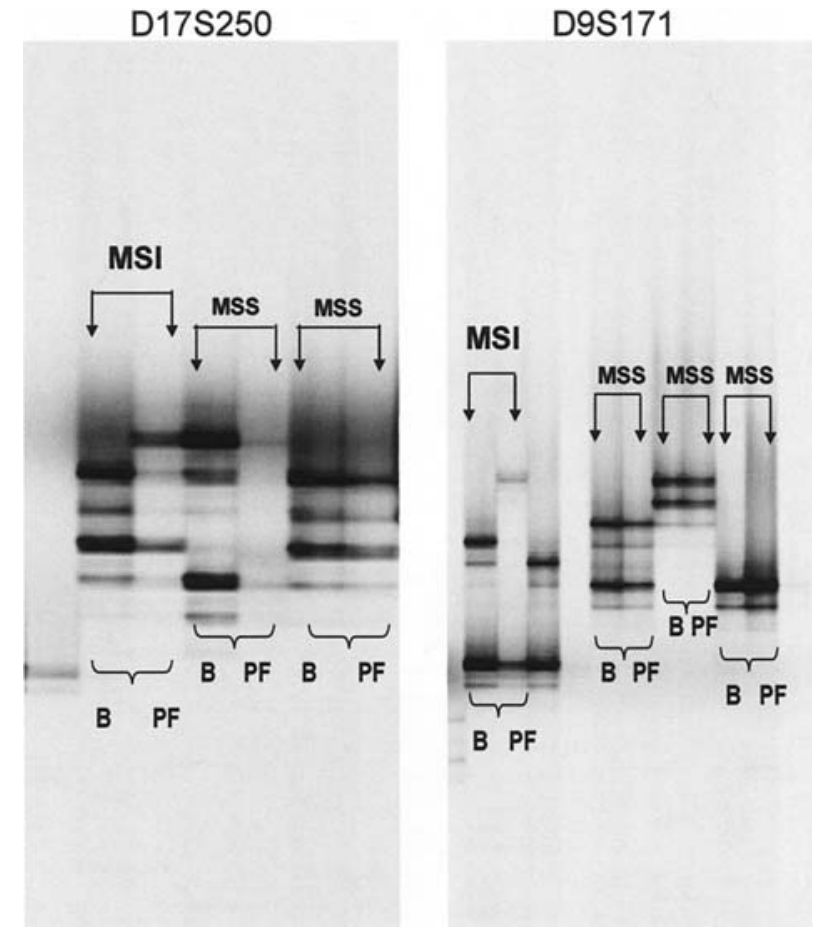

Figure 1. Representative electrophoretic patterns of microsatellite instability (MSI) and microsatellite stability (MSS) in two microsatellite markers (D17S250, D9S171). B, blood-extracted DNA; PF, pleural fluid-extracted DNA.

malignancy (ME) and in the pleural fluid of 17 patients with tuberculous pleurisy (TB), in four microsatellite markers, D3S1234, D3S1285, D9S171 and TP53. Twenty-five ME cases $(63 \%)$ exhibited microsatellite alterations ( $\mathrm{LOH}$ or $\mathrm{MI})$ in at least one marker, while in TB patients, these markers had a $35 \%$ positive rate. They concluded that subjects with tuberculous pleurisy may not comprise a strict control group and the false positive rate made these markers unlikely to be diagnostic (22). In another study, Woenckhaus et al (23) investigated genetic alterations in pleural fluid (supernatants and cellular sediments) from 14 patients with malignancy and 6 with benign pleural effusions using 12 microsatellite markers. Microsatellite analyses detected molecular alterations in $91.6 \%$ of the matched tumor tissue samples and in $71 \%$ of the malignant pleural supernatants while four markers (D2S1266, D3S1300, D3S1539 and D12S335) did not show any molecular alterations in pleural supernatants. However, the molecular analysis of the cellular sediment revealed a sensitivity of only $7 \%$, which is conflicting with the results by Lee et al (22). Woenckhaus et al (23) also reported that tumor DNA is also detectable in cell-free body fluid, as the supernatant. Authors concluded that the higher concentration of free nucleic acid of tumor cells in cell-free pleural super-natants can be explained by the selective growth advances of tumor cells, possible passive leakage of tumor DNA, or active secretion during tumor progression (23).

The first of the aforementioned studies (22) detected MSI in $15 \%$ and $\mathrm{LOH}$ in $25 \%$ in the microsatellite marker D3S1234, of patients with malignant pleural effusions respectively (22). Contrary to this report, we detected MSI or LOH in this marker in only two out of 23 patients with lung cancer (8.6\%).
No metastatic malignancy showed any MSI or LOH in the pleural cell pellet. In addition, we detected LOH in 1 patient (4.5\%) with parapneumonic pleural effusion, while Lee and coworkers reported $\mathrm{LOH}$ in three of 17 patients $(17.6 \%)$ with tuberculous pleural effusion (22). This marker is located in the chromosomal position 3p14 encoding the fragile histidine triad gene (FHIT). The FHIT gene is a frequent target of deletions in lung cancer and its restoration in Fhit-negative cancer cell lines suppresses tumorigenicity and induces apoptosis $(22,24,29,30)$.

The same study by Lee et al, showed MSI and LOH in 10 (25\%) and in only 1 patient (3\%) respectively, in the microsatellite marker, D9S171, with malignant pleural effusion (22). In our analysis, 1 patient (3.8\%) with non-small cell lung cancer exhibited MSI in D9S171. This marker is located in the chromosomal region 9p22-p21 encoding for a tumor suppressor gene (TSGs), tumor suppressor candidate 1 , TUSC1 $(23,31)$. Loss of heterozygosity (LOH) studies indicate that genetic alterations of chromosome 9p occur in numerous tumor types, suggesting the presence of TSGs on chromosome $9 \mathrm{p}$ critical in carcinogenesis (31).

However, we did not detect any MSI or LOH in the three microsatellite markers, D12S363, D5S346 and TP53, encoding for the KRAS oncogene, adenomatous polyposis coli (APC) and the tumor protein p53 (TP53) respectively. In addition, conflicting results have been reported in the current literature $(22,23)$. A previous report $(23)$ detected $\mathrm{LOH}$ in the microsatellite marker D12S363 only in one tumor-associated case, when the cellular pellet fraction has been evaluated, which is also in accordance with our results (23). On the other hand, when the supernatant of the pleural fluid was analyzed by the same investigators, $\mathrm{LOH}$ and MSI were detectable in higher percentages (23). In this study, LOH was detected in D12S363 and D5S346 in 9 out of 14 patients, whereas one patient showed MSI with the aforementioned markers (23). The ras family genes were originally identified as oncogenes in acutely transforming retroviruses (32). Three highly homologous ras proteins are encoded by the KRAS, HRAS and NRAS genes. KRAS mutations occur in more than $90 \%$ of pancreatic adenocarcinomas, in approximately $40 \%$ of colorectal cancers and $33 \%$ of non-small cell lung carcinomas (NSCLC) (33).

Furthermore, we did not detect any LOH and/or MSI in the TP53Alu marker, located in 17p13.1 and encoding for tumor protein p53 (TP53). Mutations in the TP53 gene are also relatively frequent in many cancer types, including lung cancers (34). Lung cancers that arise in never smokers rarely have KRAS gene mutations, and their TP53 gene mutations are seldom $\mathrm{G} \rightarrow \mathrm{T}$ transversions $(35,36)$, suggesting that these cancers arise in response to exposure to carcinogens other than those present in tobacco smoke. Lee and coworkers (22) have found $\mathrm{LOH}$ in 6 patients with malignant pleural effusion $(15 \%)$, in comparison with one $(6 \%)$ detected in TB pleural effusion (22). MSI, on the other hand, was detected in 3 patients with neoplastic pleural effusion $(8 \%)$, while no instability was found in TB effusion (22).

We detected MSI in the microsatellite marker D17S250, in 1 patient with non-small cell lung cancer, while the same patient exhibited MSI in two more different microsatellite markers, D9S171, D3S134. The contribution of the abnormal 
DNA mismatch repair system to non-small cell lung cancer tumorigenesis is controversial (37). Microsatellite instability is caused mainly by dysfunction of hMLH1, where aberrant hypermethylation (HM) of its promoter region is involved (38). A recent report evaluated the hMLH1 HM and MSI phenotype by using the D17S250 and four more microsatellite markers in 94 non-small cell lung cancer samples (38). The authors reported that hMLH1 HM cannot be used as an alternative diagnostic marker of MSI phenotype in non-small cell lung cancer (38).

In order to summarize our results and compare them with the two previous reports $(22,23)$ there are issues to be considered. First, in our study a relevant, larger control group was included, which was not the case in the previous reports $(22,23)$. Our control group included not only tuberculosis pleural effusions but also parapneumonic and transudes. Secondly, although we have used additional methods to ultraconcentrate the pleural fluid solution for maximum cell recovery and DNA extraction, we could not verify the results of Lee et al (22), since we found only one case of LOH in a parapneumonic effusion, while Lee and coworkers found a $35 \%$ positive rate in tuberculous pleurisy (22). They also reported $63 \% \mathrm{LOH}$ and/or MSI positivity in at least one out of four MSI markers, while we have shown genetic alterations only in $7.6 \%$ of patients with malignant effusion using 6 microsatellite markers in 5 chromosomal loci.

In conclusion, our study showed that the molecular analysis of microsatellite DNA of the pleural cellular sediment could not increase the sensitivity of the conventional cytology. Our results are in agreement with those of Woenckhaus et al (23) regarding cellular sediment where its molecular analysis revealed positivity of only $7 \%$ (23), whereas they are in conflict with the results of Lee et al (22).

Further studies using numerous MSI markers and additional molecular procedures that should ideally not fractionate the cell pellets, which could diminish the likelihood to detect tumor cells, are needed to increase sensitivity and diagnostic yield in the malignant cell detection in neoplastic pleural effusions. Nevertheless, the detection of tumor DNA in cell-free body fluids, such as the supernatant, should be re-evaluated in larger studies.

\section{References}

1. Black RJ, Bray F, Ferlay J, et al: Cancer incidence and mortality in the European Union: cancer registry data and estimates of national incidence for 1990. Eur J Cancer 33: 1075-1107, 1997.

2. Marel M, Stastny B, Melinova L, Svandova E and Light RW: Diagnosis of pleural effusions. Experience with clinical studies, 1986-1990. Chest 107: 1598-1603, 1995.

3. Fenton KN and Richardson JD: Diagnosis and management of malignant pleural effusions. Am J Surg 170: 69-74, 1995.

4. Greenlee RT, Hill-Harmon MB, Murray T, et al: Cancer statistics, 2001. CA Cancer J Clin 51: 15-36, 2001.

5. Garcia-Bonafe $M$ and Moragas A: Differential diagnosis of malignant and reactive cells from serous effusions: image and texture analysis study. Anal Cell Pathol 12: 85-98, 1996.

6. Kjellberg SI, Dresler CM and Goldberg M: Pleural cytologies in lung cancer without pleural effusions. Ann Thorac Surg 64: 941-944, 1997.

7. Martensson G, Pettersson K and Thiringer G: Differentiation between malignant and non-malignant pleural effusion. Eur J Respir Dis 67: 326-334, 1985.

8. Nance KV, Shermer RW and Askin FB: Diagnostic efficacy of pleural biopsy as compared with that of pleural fluid examination. Mod Pathol 4: 320-324, 1991.
9. Motherby H, Nadjari B, Friegel P, Kohaus J, Ramp U and Bocking A: Diagnostic accuracy of effusion cytology. Diagn Cytopathol 20: 350-357, 1999.

10. Rodenhuis S and Slebos RJC: Clinical significance of ras oncogene activation in human lung cancer. Cancer Res 52: S2665-S2669, 1992.

11. Boutin C, Viallat JR, Cargnino P and Farisse P: Thoracoscopy in malignant pleural effusions. Am Rev Respir Dis 124: 588-592, 1981.

12. Samara K, Zervou M, Siafakas NM and Tzortzaki EG: Microsatellite DNA instability in benign lung diseases. Respir Med 100: 202-211, 2006.

13. Froudarakis ME, Sourvinos G, Fournel P, Bouros D, Vergnon JM, Spandidos DA and Siafakas NM: Microsatellite instability and loss of heterozygosity at chromosomes 9 and 17 in non-small cell lung cancer. Chest 113: 1091-1094, 1998.

14. Siafakas NM, Tzortzaki EG, Sourvinos G, Bouros D, Tzanakis N, Kafatos A and Spandidos DA: Microsatellite DNA instability in COPD. Chest 116: 47-51, 1999.

15. Vassilakis DA, Sourvinos G, Spandidos DA, Siafakas NM and Bouros D: Frequent genetic alterations at the microsatellite level in cytologic sputum samples of patients with idiopathic pulmonary fibrosis. Am J Respir Crit Care Med 162: 1115-1119, 2000.

16. Paraskakis E, Sourvinos G, Passam F, Tzanakis N, Tzortzaki EG, Zervou M, Spandidos DA and Siafakas NM: Microsatellite DNA instability and loss of heterozygosity in bronchial asthma. Eur Respir J 22: 951-955, 2003.

17. Zervou MI, Tzortzaki EG, Makris D, Gaga M, Zervas E, Economidou E, Tsoumakidou M, Tzanakis N, Milic-Emili and Siafakas NM: Differences in microsatellite DNA level between asthma and chronic obstructive pulmonary disease. Eur Respir J 28: 472-478, 2006.

18. Sourvinos G, Kiaris H, Tsikkinis A, Vassilaros S and Spandidos DA: Microsatellite instability and loss of heterozygosity in primary breast tumours. Tumour Biol 18: 157-166, 1997.

19. Sourvinos G, Tsatsanis C and Spandidos DA: Overexpression of the Tpl-2/Cot oncogene in human breast cancer. Oncogene 18: 4968-4973, 1999

20. Miyakis S and Spandidos DA: Allelic loss in breast cancer. Cancer Detect Prev 26: 426-434, 2002.

21. Arvanitis DA, Papadakis E, Zafiropoulos A and Spandidos DA: Fractional allele loss is a valuable marker for human lung cancer detection in sputum. Lung Cancer 40: 55-66, 2003.

22. Lee JH, Hong YS, Ryu JS and Chang JH: p53 and FHIT mutations and microsatellite alterations in malignancy-associated pleural effusion. Lung Cancer 44: 33-42, 2004.

23. Woenckhaus M, Grepmeier U, Werner B, Schulz C, Rockmann F, Wild PJ, Rockelein G, Blaszyk H, Schuierer M, Hofstaedter F, Hartmann A and Dietmaier W: Microsatellite analysis of pleural supernatants could increase sensitivity of pleural fluid cytology. J Mol Diagn 7: 517-524, 2005.

24. Toledo G, Sola JJ, Lozano MD, Soria E and Pardo J: Loss of FHIT protein expression is related to high proliferation, low apoptosis and worse prognosis in non-small cell lung cancer. Mod Pathol 17: 440-448, 2004

25. Wiest JS, Franklin WA, Otstot JT, Forbey K, Varella-Garcia M, Rao K, Drabkin H, Gemmill R, Ahrent S, Sidransky D, Saccomanno G, Fountain JW and Anderson MW: Identification of a novel region of homozygous deletion on chromosome $9 p$ in squamous cell carcinoma of the lung: the location of a putative tumor suppressor gene. Cancer Res 57: 1-6, 1997.

26. Divine KK, Pulling LC, Marron-Terada PG, Liechty KC, Kang T, Schwartz AG, Bocklage TJ, Coons TA, Gilliland FD and Belinsky SA: Multiplicity of abnormal promoter methylation in lung adenocarcinomas from smokers and never smokers. Int $\mathbf{J}$ Cancer 114: 400-405, 2005.

27. Sarkar FH, Valdivieso M, Borders J, et al: A universal method for the mutational analysis of K-ras and p53 gene in non-small cell lung cancer using formalin-fixed paraffin-embedded tissue. Diagn Mol Pathol 4: 266-273, 1995.

28. Shigematsu H, Lin L, Takahashi T, Nomura M, Suzuki M, Wistuba II, Fong KM, Lee H, Toyooka S, Shimizu N, Fujisawa T, Feng Z, Roth JA, Herz J, Minna JD and Gazdar AF: Clinical and biological features associated with epidermal growth factor receptor gene mutations in lung cancers. J Natl Cancer Inst 97: 339-346, 2005.

29. Kim CH, Yoo JS, Lee CT, Kim YW, Han SK, Shim YS and Yoo CG: FHIT protein enhances paclitaxel-induced apoptosis in lung cancer cells. Int J Cancer 118: 1692-1698, 2006. 
30. Roz L, Andriani F, Ferreira CG, Giaccone G and Sozzi G: The apoptotic pathway triggered by the Fhit protein in lung cancer cell lines is not affected by Bcl-2 or Bcl-x(L) overexpression. Oncogene 23: 9102-9110, 2004.

31. Shan Z, Parker T and Wiest JS: Identifying novel homozygous deletions by microsatellite analysis and characterization of tumor suppressor candidate 1 gene, TUSC1, on chromosome 9p in human lung cancer. Oncogene 23: 6612-6620, 2004.

32. Der CJ, Krontiris TG and Cooper GM: Transforming genes of human bladder and lung carcinoma cell lines are homologous to the ras genes of Harvey and Kirsten sarcoma viruses. Proc Natl Acad Sci USA 79: 3637-3640, 1982.

33. Adjei AA: Blocking oncogenic Ras signaling for cancer therapy. J Natl Cancer Inst 93: 1062-1074, 2001.

34. Sanz-Ortega J, Roig F, Al-Mousa MM, Saez MC, Munoz A, Sanz-Esponera J and Callol L: $17 \mathrm{p} 13$ (p53 locus), 5q21 (APC locus) and 9p21 (p16 locus) allelic deletions are frequently found in oral exfoliative cytology cells from smoker patients with nonsmall cell lung cancer. Histol Histopathol 22: 541-545, 2007.
35. Le Calvez F, Mukeria A, Hunt JD, Kelm O, Hung RJ, Taniere P, Brennan P, Boffetta P, Zaridze DG and Hainaut P: TP53 and KRAS mutation load and types in lung cancers in relation to tobacco smoke: distinct patterns in never, former, and current smokers. Cancer Res 65: 5076-5083, 2005.

36. Vahakangas KH, Bennett WP, Castren K, Welsh JA, Khan MA, Blomeke B, Alavanja MC and Harris CC: p53 and K-ras mutations in lung cancers from former and never-smoking women. Cancer Res 61: 4350-4356, 2001.

37. Shayek H, Krupsky M, Yaron A, Simansky DA and Friedman E: Genetic analyses of non-small cell lung cancer in Jewish Israeli patients. Isr Med Assoc J 8: 159-163, 2006.

38. Okuda T, Kawakami K, Ishiguro K, Oda M, Omura K and Watanabe G: The profile of hMLH 1 methylation and microsatellite instability in colorectal and non-small cell lung cancer. Int J Mol Med 15: 85-90, 2005. 